\title{
Deskripsi Hasil Belajar Mata Kuliah Pengetahuan Komputer Mahasiswa Agribisnis Semester Genap Tahun Akademik 2017/2018
}

\author{
Abdul Zahir ${ }^{*}$, Jusrianto ${ }^{2}$ \\ 1, 2 Universitas Cokroaminoto Palopo \\ ‘abdulzahir86@gmail.com
}

\section{Abstrak}

Penelitian ini merupakan penelitian kuantitatif dengan jenis penelitian ex-post facto, yang dilakukan untuk meneliti variabel atau peristiwa yang telah terjadi dan kemudian merunut ke belakang melalui data tersebut untuk menemukan faktor-faktor penyebab terjadinya peristiwa yang diteliti. Teknik sampling yang digunakan adalah population sampling, yakni populasi sekaligus sebagai sampel. Jumlah sampelnya adalah 153 orang mahasiswa pada Program Studi Agribisnis Fakultas Pertanian Universitas Cokroaminoto Palopo yang memprogramkan dan mengikuti mata kuliah pengetahuan komputer. Seratus empat puluh satu mahasiswa lulus dalam mata kuliah ini. Kelas 2A lebih banyak mahasiswa yang mendapatkan nilai $\mathrm{A}$ dibanding mahasiswa di kelas lainnya. Pada tujuh kategori penilaian, mahasiswa kelas 2A mendapatkan ketujuh nilai tersebut. Kelas $2 \mathrm{~B}$ lebih banyak mahasiswanya yang mendapatkan nilai $B$ dibanding nilai dan kelas lain. Tidak ada mahasiswa yang mendapatkan nilai $\mathrm{C}$ dan $\mathrm{D}$ di kelas $2 \mathrm{~B}$. Kelas $2 \mathrm{C}$ tidak memperlihatkan unjuk kerja dominan dalam penilaian. Semua kategori nilai didapatkan dan pada nilai $A$, mahasiswa kelas 2C memperlihatkan unjuk kerja yang negatif, yakni paling sedikit mahasiswa yang memperolehnya. Kelas 2D merupakan kelas dengan mahasiswa yang terbanyak mendapatkan nilai $E$ dan tidak ada satupun mahasiswanya mendapatkan nilai $D$.

Kata Kunci: Hasil Belajar, Ex-post facto, Nilai

\section{Pendahuluan}

Pendidikan atau pengajaran merupakan salah satu usaha yang bersifat sadar tujuan yang dengan sistematis terarah pada perubahan tingkah laku menuju kedewasaan anak didik. Oleh karena itu, pendidikan mempunyai peran yang sangat penting bagi manusia karena pendidikan tidak akan berhenti pada satu generasi saja tetapi untuk seterusnya (Sardiman, 2002:12). Dan hasil belajar merupakan indikator keberhasilan pelaksanaan pendidikan.

Hamalik (2008:155) berpendapat bahwa hasil belajar tampak sebagai terjadinya perubahan tingkah laku pada diri peserta didik, yang dapat diamati dan diukur dalam bentuk perubahan pengetahuan sikap dan keterampilan. Oleh karena itu, dosen, wali mahasiswa hingga lingkungan perguruan tinggi sangat dibutuhkan dalam meningkatkan hasil belajar juga memahami para mahasiswa dalam menghadapi kesulitan dalam belajar. Dalam pembelajaran pengetahuan komputer, dosen hendaknya mengupayakan pengelolaan pembelajaran yang bermutu. Salah satu peningkatan kualitas tersebut berupa penggunaan model pembelajaran yang lebih efektif akan lebih mudah dilaksanakan siswa dan memiliki fungsi efektif dalam menunjang pencapaian tujuan pembelajaraan. 
Salah satu unit kompetensi yang ditetapkan dalam Standar Kompetensi Kerja Nasional Indonesia (SKKNI) adalah kemampuan mengoperasikan komputer. Unit kompetensi ini berkaitan dengan keterampilan, pengetahuan dan sikap kerja yang dibutuhkan dalam mengoperasikan aplikasi komputer sesuai dengan kurikulum yang ditetapkan oleh perguruan tinggi. Unit ini terdiri atas 4 elemen kompetensi yaitu: mengetahui komputer dan perkembangannya beserta sistem yang ada dalam komputer, mampu membedakan hardware dan software dan bisa menjelaskan fungsi-fungsinya, mampu mengetahui jaringan komputer dan internet beserta pemanfaatannya, dan mampu menggunakan komputer berupa perangkat lunak untuk pembelajaran dan bisnis.

Mata kuliah pengetahuan komputer merupakan salah satu mata kuliah yang wajib diambil oleh mahasiswa Universitas Cokroaminoto Palopo. Mata kuliah ini menggunakan empat metode pembelajaran. Keempat metode itu adalah ceramah, diskusi, simulasi dan praktik. Keempat metode ini dilaksanakan untuk memenuhi dan merangkum semua capaian pembelajaran.

Program Studi Agribisnis Fakultas Pertanian Universitas Cokroaminoto Palopo yang memprogramkan mata kuliah pengetahuan komputer sebanyak empat kelas. Mahasiswa yang mengikuti mata kuliah pengetahuan komputer sebanyak empat kelas dan tidak terdistribusi secara merata. Perbedaan jumlah mahasiswa disetiap kelasnya akan mempengaruhi perlakuan yang diberikan oleh dosen disetiap pertemuannya.

Hal lain yang menyebabkan adanya perbedaan hasil belajar, selain perlakuan yang berbeda dikarenakan jumlah mahasiswa yang berbeda juga dikarenakan ketidakmerataan kemampuan mahasiswa dan tingkat pengetahuan awal akan komputer yang rentangnya sangat jelas perbedaannya. Mahasiswa dari pusat perkotaan, ekonomi tinggi dan status sekolah menengah yang mumpuni akan memperlihatkan unjuk kerja yang baik dalam kelas.

\section{Pengertian Hasil Belajar}

Dimyanti dan Mudjiono (2006: 3) menyatakan bahwa hasil belajar merupakan hasil dari suatu interaksi tindak belajar dan tindak mengajar. Dari sisi guru, tindak mengajar diakhiri dengan proses evaluasi hasil belajar siswa. Dari sisi siswa, hasil belajar merupakan berakhirnya penggal dan puncak proses belajar.

Sudjana (2003: 3) menyatakan hasil belajar adalah perubahan tingkah laku yang timbul misalnya dari tidak tahu menjadi tahu. Sedangkan Slameto (1988: 23) menyatakan Hasil belajar adalah hasil pengukuran dan penilaian (evaluasi) pendidikan yang tidak hanya berguna untuk mengetahui penguasaan siswa atas berbagai hal yang pernah diajarkan atau dilatihkan, melainkan juga untuk memberikan gambaran tentang pencapaian program-program pendidikan secara lebih menyeluruh. Informasi tentang hasil belajar ini dapat dipakai untuk menetapkan kenaikan kelas/tingkat, lulus dan tidak lulus, menetapkan indeks prestasi, menetapkan dan memberlakukan sanksi pendidikan, dan menetapkan pemberian Surat Tanda Tamat Belajar (ijazah).

Sukmadinata dalam Irsan (2016) menyatakan hasil belajar atau achievement merupakan realisasi atau pemekaran dari kecakapan-kecakapan potensial atau kapasitas yang dimiliki seseorang. Penguasaan hasil belajar oleh seseorang dapat dilihat dari perilakunya, baik perilaku dalam bentuk penguasaan pengetahuan, keterampilan berpikir, maupun keterampilan motorik. Hasil belajar di sekolah dapat dilihat dari penguasaan peserta didik pada mata pelajaran yang dilambangkan dengan angka-angka atau huruf, seperti huruf $A, B, C, D$ atau 
dengan angka 0 - 10 atau 0-100. Hasil belajar diukur dengan menggunakan tes hasil belajar atau tes prestasi belajar atau achievement test.

Sardiman (2002:12) mengatakan bahwa pendidikan atau pengajaran merupakan salah satu usaha yang bersifat sadar tujuan yang dengan sistematis terarah pada perubahan tingkah laku menuju kedewasaan anak didik. Oleh karena itu, pendidikan mempunyai peran yang sangat penting bagi manusia karena pendidikan tidak akan berhenti pada satu generasi saja tetapi untuk seterusnya. Dan hasil belajar merupakan indikator keberhasilan pelaksanaan pendidikan.

Hamalik (2008:155) berpendapat bahwa Hasil belajar tampak sebagai terjadinya perubahan tingkah laku pada diri peserta didik, yang dapat diamati dan diukur dalam bentuk perubahan pengetahuan sikap dan keterampilan. Oleh karena itu, dosen, wali mahasiswa hingga lingkungan perguruan tinggi sangat dibutuhkan dalam meningkatkan hasil belajar juga memahami para mahasiswa dalam menghadapi kesulitan dalam belajar. Dalam pembelajaran pengetahuan komputer, dosen hendaknya mengupayakan pengelolaan pembelajaran yang bermutu. Salah satu peningkatan kualitas tersebut berupa penggunaan model pembelajaran yang lebih efektif akan lebih mudah dilaksanakan siswa dan memiliki fungsi efektif dalam menunjang pencapaian tujuan pembelajaraan.

Kingsley membagi tiga macam hasil belajar, yakni (a) keterampilan dari kebiasaan, (b) pengetahuan dan pengertian, (c) sikap dan cita-cita (dalam udjana, 1989: 22). Sedangkan Gagne membagi lima kategori hasil belajar, yakni (a) informasi verbal, (b) keterampilan intelektual, (c) strategi kognitif, (d) sikap, dan (e) keterampilan motoris (dalam Dimyati dan Mudjiono, 2006). Selanjutnya, Bloom (Suherman, 1990) membagi hasil belajar kognitif dalam 6 tingkatan yaitu: (1) pengetahuan (knowledege), (2) pemahaman (comprehension), (3) aplikasi (application), (4) analisis (analysis), (5) sintesa (synthesis), dan (6) evaluasi (evaluation).

Hasil belajar dapat berupa dampak pengajaran dan dampak pengiring. Dampak pengajaran adalah hasil yang dapat diukur seperti nilai yang tertuang dalam rapor, ijazah, ujian, dan sebagainya dan dampak pengiring adalah terapan pengetahuan dan kemampuan dibidang lain, suatu transfer belajar. Di Universitas Cokroaminoto, hasil belajar mahasiswa akan tercetak di Sistem Informasi Manajemen dalam bentuk kartu hasil studi yang kelak akan dimiliki oleh mahasiswa. Sedangkan untuk dosen, hasil belajar mahasiswa per kelas dapat dicetak dalam bentuk daftar nilai hasil belajar.

\section{Mata Kuliah Pengetahuan Komputer}

Pengetahuan Komputer merupakan mata kuliah wajib di Universitas Cokroaminoto Palopo, sehingga mahasiswa harus memahami mata kuliah ini serta dapat menerapkan pengetahuannya dalam kehidupan. Mata kuliah pengetahuan komputer berbobot 2 sks dan diprogramkan diawal perkuliahan (semester 1 untuk Fakultas Teknik Komputer dan Fakultas Keguruan dan IImu Pendidikan dan semester 2 untuk Fakultas Pertanian dan Fakultas Sains).

Mata kuliah ini membahas tentang pemanfaatan komputer dalam kehidupan sehari-hari meliputi aplikasi Microsoft Office (Ms. Word, Ms. Powerpoint dan Ms. Excel) dan pemanfaatan internet (e-mail, e-learning, blog dan website). Mata kuliah ini memberikan bekal pengetahuan dan keterampilan sehingga menghasilkan mahasiswa yang mengerti tentang pengertian komputer, sejarah komputer, hardware dan software komputer, dan pemanfaatan komputer. Pun mahasiswa dapat mengaplikasan dan menggunakan perangkat komputer dalam kehidupan sehari-harinya. 


\section{Program Studi Agribisnis Fakultas Pertanian}

Fakultas Pertanian (Faperta) adalah salah satu fakultas di lingkungan Universitas Cokroaminoto Palopo. Program Studi Agribisnis sebelumnya bernama Program Studi Sosial Ekonomi Pertanian yang kemudian berdasarkan SK Direktur Jenderal Pendidikan Tinggi Nomor 163/DIKTI/Kep./2007 tanggal 29 November 2007 berubah nama menjadi Program Studi Agribisnis.

Program Studi Agribisnis terbentuk secara formal sejak tahun 1995 berdasarkan Nomor SK pendirian Program Studi 014/D/0/1995, tanggal pendirian 23 Februari 1995. Pada Tahun 2011 dikeluarkan oleh DIKTI dengan Nomor SK Izin Operasional: 8830/D/T/K-IX/2011, Tanggal SK Izin Operasional: 28 September 2011. Kinerja Prodi Agribisnis melaju sangat pesat, terbukti dikeluarkannya akreditasi B dari BAN-PT, Nomor SK BAN-PT: 053/SK/BAN-PT/Akred/S/II/2014, Tanggal 01 Februari 2014. Akreditasi berlaku selama 5 (lima) tahun.

Visi dari Program Studi Agribisnis adalah "Menjadi program studi yang bermutu tinggi dan mampu menghasilkan tenaga profesional, dan memiliki mental wirausaha pada tahun 2024."

Misi yang dilaksanakan dalam rangka mewujudkan visi adalah:

1. Menyelenggarakan pendidikan di bidang agribisnis untuk menghasilkan tenaga profesional, berkarakter dan memiliki mental wirausaha sesuai perkembangan IPTEKS dan tuntutan dunia kerja.

2. Mengembangkan IPTEKS di bidang Agribisnis melalui pelaksanaan penelitian

3. Membina masyarakat dalam penerapan IPTEKS melalui pelaksanaan Pengabdian Kepada Masyarakat.

Tujuan yang dicapai oleh Program Studi Agribisnis adalah:

1. Dihasilkan lulusan berkarakter dan memiliki mental wirausaha dan mampu membuka lapangan kerja.

2. Dihasilkan manajer handal dengan kemampuan manajerial yang sangat baik dengan etika dan wawasan pertanian berkelanjutan

3. Dihasilkan karya ilmiah dan karya inovatif lainnya melalui kegiatan penelitian.

4. Membina masyarakat dalam penerapan dan pengembangan IPTEKS.

5. Terjalinnya kerjasama dengan stakeholder dalam pelaksanaan Tridharma Perguruan Tinggi dan pengembangan Program Studi.

6. Terwujudnya sarana dan prasarana berbasis teknologi informasi mendukung visi dan misi perguruan tinggi.

\section{Metode Penelitian}

Penelitian ini merupakan penelitian kuantitatif dengan jenis penelitian ex-post facto. Ex-post facto adalah penelitian yang dilakukan untuk meneliti variable atau peristiwa yang telah terjadi dan kemudian merunut kebelakang melalui data tersebut untuk menemukan faktor-faktor penyebab terjadinya peristiwa yang diteliti. Pendekatan penelitiannya adalah pendekatan dasar kausal komparatif (Causal compararative research) melibatkan kegiatan peneliti yang diawali dengan mengidentifikasi pengaruh variabel satu terhadap variabel lainnya, kemudian dia berusaha mencari kemungkinan variabel penyebabnya. Penelitian ini bertujuan untuk mengungkapkan keadaan atau gejala suatu objek atau variabel yang ada. Dalam hal ini yang 
akan diungkapkan gejalanya adalah karakteristik hasil belajar diempat kelas yang berbeda pada mata kuliah pengetahuan komputer di Program Studi Agribisnis Fakultas Pertanian Universitas Cokroaminoto Palopo.

Penelitian ini dilaksanakan di Universitas Cokroaminoto Palopo dan dilakukan setelah proses pelaksanaan ujian akhir semester dan remedial dilaksanakan, yakni dimulai pada tanggal 2 sampai 16 Juli 2018.

Penelitian ini adalah menganalisa hasil belajar mahasiswa. Populasi dalam penelitian ini adalah daftar nilai hasil belajar mata kuliah pengetahuan komputer Program Studi Agribisnis Fakultas Pertanian Universitas Cokroaminoto Palopo Semester Genap Tahun Akademik 2017/2018 di Palopo yang terdiri dari empat kelas yaitu kelas 2A, 2B, 2C dan 2D. Jumlah mahasiswa dapat dilihat pada tabel 3.1.

Tabel 1. Tabel Jumlah Mahasiswa

\begin{tabular}{lllll}
\hline Siswa & 2A & 2B & 2C & 2D \\
\hline Laki-laki & 7 & 11 & 18 & 21 \\
Perempuan & 28 & 29 & 22 & 17 \\
Jumlah & 35 & 40 & 40 & 38 \\
\hline
\end{tabular}

Teknik sampling yang digunakan untuk mendapatkan sampel dalam penelitian ini adalah population sampling, yakni populasi sekaligus sebagai sampel. Jumlah sampelnya adalah 153 orang/ mahasiswa.

Metode yang dipergunakan dalam mengumpulkan data adalah metode dokumentasi. Metode ini dipakai untuk mendapatkan seperangkat daftar nilai hasil belajar mata kuliah pengetahuan komputer Program Studi Agribisnis Fakultas Pertanian Universitas Cokroaminoto Palopo Semester Genap Tahun Akademik 2017/2018 yang didapatkan dari Sistem Informasi Manajamen Universitas Cokroaminoto Palopo.

Data yang diperoleh dianalisis dengan menggunakan teknik analisis statistik, yaitu analisis statistik deskripsi. Dalam penelitian ini, analisis statistik dekriptif digunakan untuk mendeskripsikan setiap variabel penelitian yaitu hasil belajar belajar mata kuliah pengetahuan komputer Program Studi Agribisnis Fakultas Pertanian Universitas Cokroaminoto Palopo Semester Genap Tahun Akademik 2017/2018. Hasil analisis statistik deskriptif meliputi penyajian data melalui tabel, grafik, mean, median, modus, standar deviasi, dan perhitungan persentase.

Data tentang hasil belajar belajar mata kuliah pengetahuan komputer Program Studi Agribisnis Fakultas Pertanian Universitas Cokroaminoto Palopo Semester Genap Tahun Akademik 2017/2018 diperoleh peneliti melalui Sistem Informasi Manajamen Universitas Cokroaminoto Palopo. Data hasil belajar dikategorikan secara kuantitatif bedasarkan kriteria pengkategorian yang ditetapkan oleh Universitas Cokroaminoto Palopo. Berikut di bawah ini Kriteria Pengkategorian Hasil Belajar.

Tabel 2. Kriteria Pengkategorian Hasil Belajar

\begin{tabular}{ll}
\hline Interval Hasil Belajar & Mutu \\
\hline $85.00-100.00$ & $\mathrm{~A}$ \\
$75.00-84.99$ & $\mathrm{~B}+$ \\
$70.00-74.99$ & $\mathrm{~B}$ \\
$65.00-69.99$ & $\mathrm{C}+$ \\
$55.00-64.99$ & $\mathrm{C}$ \\
$40.00-54.99$ & $\mathrm{D}$ \\
$0.00-39.00$ & $\mathrm{E}$ \\
\hline
\end{tabular}




\section{Hasil Penelitian \& Pembahasan}

Mahasiswa Program Studi Agribisnis Fakultas Pertanian Universitas Cokroaminoto Palopo Semester Genap Tahun Akademik 2017/2018 yang memprogramkan dan mengikuti mata kuliah pengetahuan komputer sebanyak 4 kelas (kelas 2A, 2B, 2C dan 2D) dengan jumlah mahasiswa 153 orang. Berikut akan ditampilkan distribusi hasil belajar mata kuliah pengetahuan komputer Program Studi Agribisnis Fakultas Pertanian Universitas Cokroaminoto Palopo Semester Genap Tahun Akademik 2017/2018 secara deskriptif dan didetailkan secara per kelas.

\section{Hasil Belajar Kelas $2 A$}

Kelas 2A terdapat 35 mahasiswa dengan jumlah mahasiswa laki-laki sebanyak 7 orang dan mahasiswa perempuan sebanyak 28 orang, Hasil belajar dari kelas ini dapat dilihat pada Tabel 3 dan Gambar 1 seperti di bawah ini.

Tabel 3. Hasil Belajar Kelas 2A

\begin{tabular}{ccccr}
\hline \multirow{2}{*}{$\begin{array}{c}\text { Nilai } \\
\text { Mutu }\end{array}$} & \multicolumn{2}{c}{ Jenis Kelamin } & \multirow{2}{*}{ Jumlah } & Persentase \\
\cline { 2 - 3 } Laki-Laki & Perempuan & & \\
\hline B & 1 & 6 & 7 & $20.00 \%$ \\
B & 1 & 4 & 5 & $14.29 \%$ \\
B & 1 & 4 & 5 & $14.29 \%$ \\
C+ & 2 & 10 & 12 & $34.29 \%$ \\
C & 1 & 2 & 3 & $8.57 \%$ \\
D & 0 & 1 & 1 & $2.86 \%$ \\
E & 1 & 1 & 2 & $5.71 \%$ \\
\hline Total & $\mathbf{7}$ & $\mathbf{2 8}$ & $\mathbf{3 5}$ & $\mathbf{1 0 0 \%}$ \\
\hline
\end{tabular}

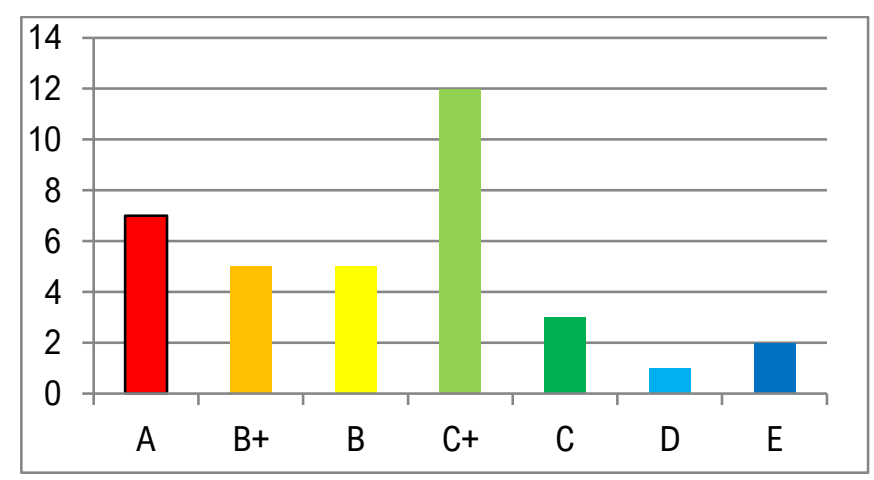

Gambar 1. Diagram sebaran hasil belajar mahasiswa kelas $2 \mathrm{~A}$

Tabel 3 dan Gambar 1 memperlihatkan bahwa jumlah mahasiswa di kelas $2 \mathrm{~A}$ yang mendapatkan nilai $B+$ dan $B$ sama yakni masing-masing 5 orang. Nilai $C+$ merupakan nilai yang paling banyak mahasiswa mendapatkannya, sebanyak 12 orang (34.29\%). Dibanding nilai lainnya, nilai $D$ dan $E$ hanya terdapat 1 dan 2 orang. Hal memberikan indikasi bahwa 32 mahasiswa terkategori lulus, mesti yang hanya mendapatkan nilai $A$ hanya 7 mahasiswa saja.

Tabel 3 memperlihatkan bahwa mahasiswa laki-laki yang jumlahnya hanya 7 orang tidak ada yang mendapatkan nilai $D$. Berbeda dengan mahasiswa perempuan, semua nilai mutu ada yang mendapatkannya. 


\section{Hasil Belajar Kelas 2B}

Kelas 2B terdapat 40 mahasiswa dengan jumlah mahasiswa laki-laki sebanyak 11 orang dan mahasiswa perempuan sebanyak 29 orang, Hasil belajar dari kelas ini dapat dilihat pada Tabel 4 dan Gambar 2 seperti di bawah ini.

Tabel 4. Hasil Belajar Kelas 2B

\begin{tabular}{ccccr}
\hline \multirow{2}{*}{$\begin{array}{c}\text { Nilai } \\
\text { Mutu }\end{array}$} & \multicolumn{2}{c}{ Jenis Kelamin } & \multirow{2}{*}{ Jumlah } & Persentase \\
\cline { 2 - 3 } & Laki-Laki & Perempuan & & \\
\hline A & 0 & 3 & 3 & $7.50 \%$ \\
B+ & 2 & 5 & 7 & $17.50 \%$ \\
B & 7 & 12 & 19 & $47.50 \%$ \\
C+ & 1 & 9 & 10 & $25.00 \%$ \\
C & 0 & 0 & 0 & $0.00 \%$ \\
D & 0 & 0 & 0 & $0.00 \%$ \\
E & 1 & 0 & 1 & $2.50 \%$ \\
\hline Total & $\mathbf{1 1}$ & $\mathbf{2 9}$ & $\mathbf{4 0}$ & $\mathbf{1 0 0 \%}$ \\
\hline
\end{tabular}

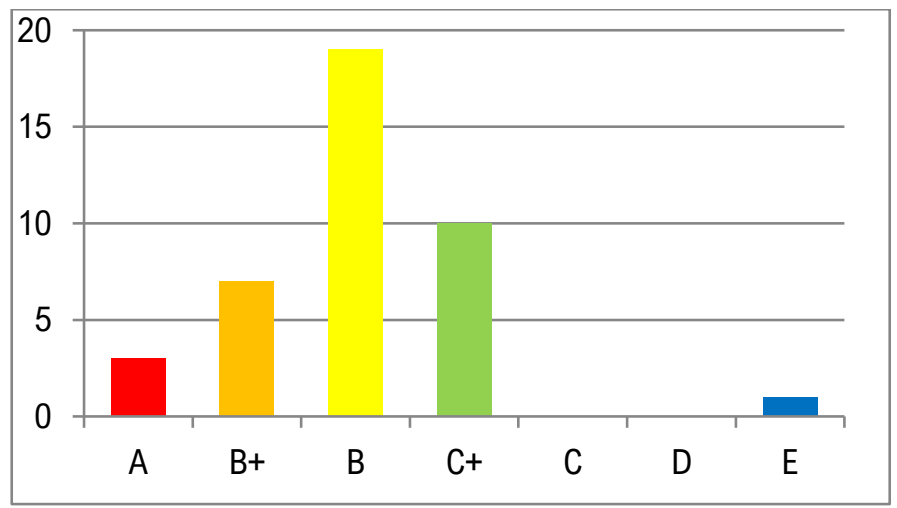

Gambar 2. Diagram sebaran hasil belajar mahasiswa kelas 2B

Tabel 4 dan Gambar 2 memperlihatkan bahwa jumlah mahasiswa di kelas 2B yang mendapatkan nilai $B$ lebih banyak dibanding nilai lain, yakni sebanyak 19 orang (47.50\%). Nilai $\mathrm{C}+$, nilai $\mathrm{B}+$ dan nilai $\mathrm{A}$ berturut-turut didapatkan oleh mahasiswa berdasarkan jumlah yang mendapatkannya (10 orang, 7 orang dan 3 orang). Dibanding nilai lainnya, nilai $C$ dan $D$ tidak ada satu mahasiswa yang mendapatkannya. Hal memberikan indikasi bahwa 39 mahasiswa terkategori lulus dan hanya 1 mahasiswa yang tidak lulus karena mendapatkan nilai $\mathrm{E}$.

Tabel 4 memperlihatkan bahwa mahasiswa laki-laki yang jumlahnya hanya 11 orang, lebih sedikit dibanding mahasiswa perempuannya. Semua mahasiswa perempuan dinyatakan lulus karena tidak ada yang mendapatkan nilai $D$ dan $E$ yang tidak lulus hanya 1 orang mahasiswa laki-laki. Hal lain diperlihatkan pada Tabel 4 bahwa yang mendapatkan nilai $A$ hanya 3 orang dan semuanya perempuan.

\section{Hasil Belajar Kelas 2C}

Kelas $2 \mathrm{C}$ terdapat 40 mahasiswa dengan jumlah mahasiswa laki-laki sebanyak 18 orang dan mahasiswa perempuan sebanyak 22 orang, Hasil belajar dari kelas ini dapat dilihat pada Tabel 5 dan Gambar 3 berikut ini. 
Tabel 5. Hasil Belajar Kelas 2C

\begin{tabular}{ccccr}
\hline \multirow{2}{*}{$\begin{array}{c}\text { Nilai } \\
\text { Mutu }\end{array}$} & \multicolumn{2}{c}{ Jenis Kelamin } & \multirow{2}{*}{ Jumlah } & Persentase \\
\cline { 2 - 3 } & Laki-Laki & Perempuan & & \\
\hline A & 0 & 1 & 1 & $2.50 \%$ \\
B+ & 3 & 2 & 5 & $12.50 \%$ \\
B & 4 & 13 & 17 & $42.50 \%$ \\
C+ & 7 & 4 & 11 & $27.50 \%$ \\
C & 2 & 0 & 2 & $5.00 \%$ \\
D & 2 & 0 & 2 & $5.00 \%$ \\
E & 0 & 2 & 2 & $5.00 \%$ \\
\hline TOTAL & $\mathbf{1 8}$ & $\mathbf{2 2}$ & $\mathbf{4 0}$ & $\mathbf{1 0 0 \%}$ \\
\hline
\end{tabular}

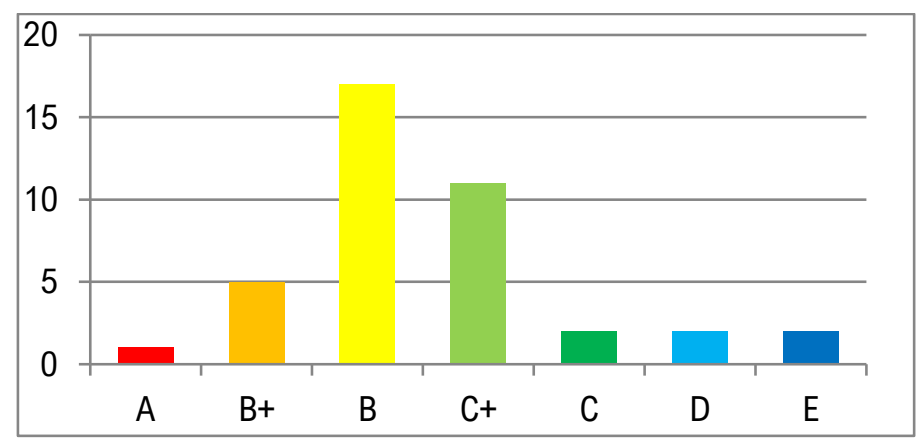

Gambar 3. Diagram sebaran hasil belajar mahasiswa kelas $2 \mathrm{C}$

Tabel 5 dan Gambar 3 memperlihatkan bahwa jumlah mahasiswa di kelas 2C yang mendapatkan nilai B lebih banyak dibanding nilai lain, yakni sebanyak 17 orang (42.50\%). Nilai $\mathrm{C}+$, nilai $\mathrm{B}+$ dan nilai $\mathrm{A}$ berturut-turut didapatkan oleh mahasiswa berdasarkan jumlah yang mendapatkannya (11 orang, 5 orang dan 1 orang). Nilai C, nilai D dan Nilai E didapatlan oleh mahasiswa masing-masing 2 orang. Hal memberikan indikasi bahwa 36 mahasiswa terkategori lulus dan ada 4 mahasiswa yang tidak lulus.

Tabel 5 memperlihatkan bahwa mahasiswa laki-laki yang jumlahnya hanya 11 orang, lebih sedikit dibanding mahasiswa perempuannya. Hanya mahasiswa perempuan yang mendapatkan nilai $A$ ( 1 orang) dan nilai $E$ (2 orang). Hanya 2 mahasiswa perempuan dinyatakan tidak lulus karena mendapatkan nilai $E$, hal yang sama terjadi pada mahasiswa laki-laki (dapat nilai $D$ ).

\section{Hasil Belajar Kelas 2D}

Kelas 2D terdapat 38 mahasiswa dengan jumlah mahasiswa laki-laki sebanyak 19 orang dan mahasiswa perempuan sebanyak 19 orang. Hasil belajar dari kelas ini dapat dilihat pada Tabel 6 dan Gambar 4 berikut.

Tabel 6. Hasil Belajar Kelas 2D

\begin{tabular}{ccccr}
\hline \multirow{2}{*}{$\begin{array}{c}\text { Nilai } \\
\text { Mutu }\end{array}$} & \multicolumn{2}{c}{ Jenis Kelamin } & \multirow{2}{*}{ Jumlah } & Persentase \\
\cline { 2 - 3 } & Laki-Laki & Perempuan & & \\
\hline A & 2 & 4 & 6 & $15.79 \%$ \\
B+ & 4 & 3 & 7 & $18.42 \%$ \\
B & 4 & 7 & 11 & $28.95 \%$ \\
C+ & 4 & 4 & 8 & $21.05 \%$ \\
C & 2 & 0 & 2 & $5.26 \%$ \\
D & 0 & 0 & 0 & $0.00 \%$ \\
E & 3 & 1 & 4 & $10.52 \%$ \\
Total & $\mathbf{1 9}$ & $\mathbf{1 9}$ & $\mathbf{3 8}$ & $\mathbf{1 0 0 \%}$ \\
\hline
\end{tabular}




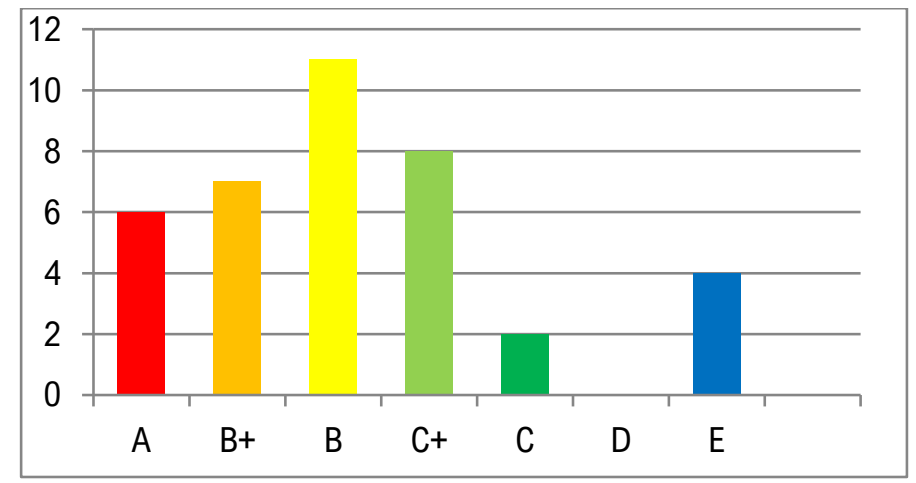

Gambar 4. Diagram sebaran hasil belajar mahasiswa kelas 2D

Tabel 6 dan Gambar 4 memperlihatkan bahwa jumlah mahasiswa di kelas 2D yang mendapatkan nilai $B$ lebih banyak dibanding nilai lain, yakni sebanyak 11 orang (28.95\%). Nilai $\mathrm{C}+$, nilai $\mathrm{B}+$ dan nilai $\mathrm{A}$ berturut-turut didapatkan oleh mahasiswa berdasarkan jumlah yang mendapatkannya (8 orang, 7 orang dan 6 orang). Nilai $\mathrm{C}$ didapatkan 2 mahasiswa dan tidak ada satupun mahasiswa yang mendapatkan nilai D. Hal memberikan indikasi bahwa 34 mahasiswa terkategori lulus dan ada 4 mahasiswa yang tidak lulus dikarenakan mendapat nilai E.

Tabel 6 memperlihatkan bahwa mahasiswa laki-laki yang jumlahnya 19 orang, sama dengan jumlah mahasiswa perempuannya. Mahasiswa perempuan lebih banyak mendapatkan nilai yang terkategori baik dibanding mahasiswa laki-lakinya. Misalnya nilai $A$, ada 4 mahasiswa perempuan yang memperolehnya sedangkanlaki-laki hanya 2 orang. Begitupun dinilai $\mathrm{B}+$ dan nilai $B$, mahasiswa perempuan lebih banyak yang mendapatkannya dibanding mahasiswa lakilaki. Pada nilai $\mathrm{C}+$, jumlah mahasiswa laki-laki dan perempuan yang mendapatkannya sama. Lebih banyak mahasiswa laki-laki yang tidak lulus dibanding mahasiswa perempuan (3:1 mahasiswa).

\section{Deskripsi Perbandingan Hasil Belajar Semua Kelas}

Mahasiswa Program Studi Agribisnis Fakultas Pertanian Universitas Cokroaminoto Palopo Semester Genap Tahun Akademik 2017/2018 yang memprogramkan dan mengikuti mata kuliah pengetahuan komputer sebanyak 4 kelas (kelas 2A, 2B, 2C dan 2D) dengan jumlah mahasiswa 153 orang. Hasil belajar dari kelas ini dapat dilihat pada Tabel 4.4 dan Gambar 4.4 seperti di bawah ini.

Tabel 7. Hasil Belajar Program Studi Agribisnis

\begin{tabular}{lrrrr}
\hline $\begin{array}{l}\text { Nilai } \\
\text { Mutu }\end{array}$ & \multicolumn{1}{c}{$\begin{array}{c}\text { Kelas } \\
\text { 2A }\end{array}$} & $\begin{array}{c}\text { Kelas } \\
\text { 2B }\end{array}$ & \multicolumn{2}{c}{ Kelas } \\
2C & $\begin{array}{c}\text { Kelas } \\
\text { 2D }\end{array}$ \\
\hline A & 7 & 3 & 1 & 6 \\
B+ & 5 & 7 & 5 & 7 \\
B & 5 & 19 & 17 & 11 \\
C+ & 12 & 10 & 11 & 8 \\
C & 3 & 0 & 2 & 2 \\
D & 1 & 0 & 2 & 0 \\
E & 2 & 1 & 2 & 4 \\
\hline Jumlah & $\mathbf{3 5}$ & $\mathbf{4 0}$ & $\mathbf{4 0}$ & $\mathbf{3 8}$ \\
\hline
\end{tabular}




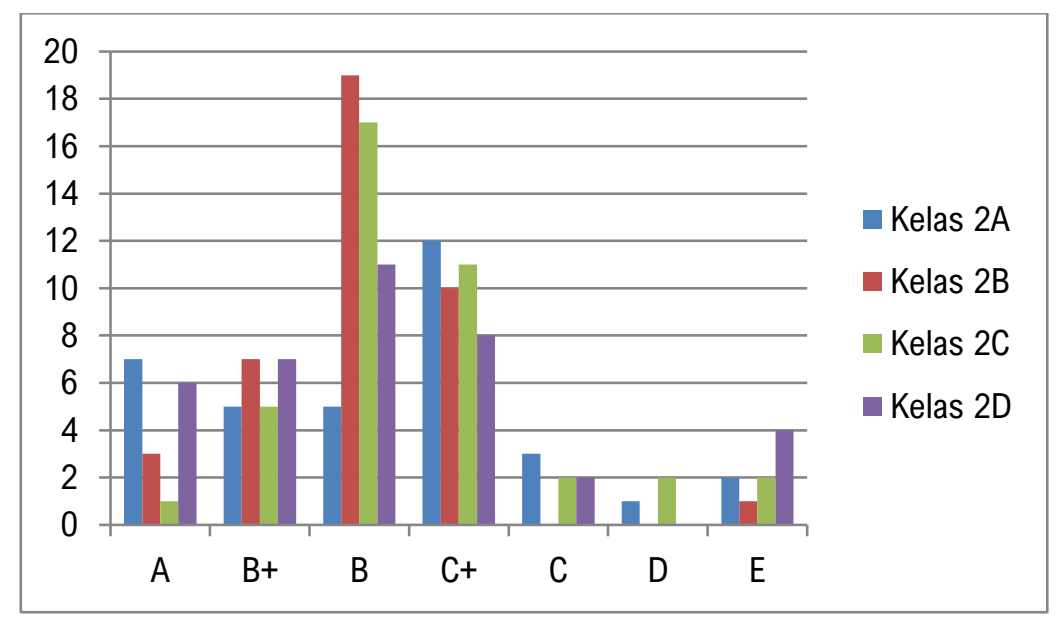

Gambar 5. Diagram sebaran hasil belajar mahasiswa Agribisnis

Tabel 7 dan Gambar 5 memperlihatkan bahwa jumlah mahasiswa terbanyak memperoleh nilai $A$ berasal dari kelas $A$ sebanyak 7 orang dan paling sedikit berasal dari kelas $C$. Kelas $A$ dan $C$ sama jumlah mahasiswanya yang mendapatkan nilai $B+$ ( 5 mahasiswa), begitupun kelas $B$ dan $D$ (7 mahasiswa). Kelas $B$ mengungguli kelas lain dalam jumlah mahasiswa memperoleh nilai B yakni 19 orang dan kelas A yang paling rendah hanya 5 orang. Mahasiswa disetiap kelasnya yang mendapatkan nilai $\mathrm{C}+$ cenderung menunjukkan perolehan yang sama, berada direntang 8-12 mahasiswa saja. Nilai $C$, nilai $D$ dan nilai $E$ merupakan nilai yang paling sedikit didapatkan oleh mahasiswa disetiap kelas. Hanya pada nilai E, di kelas D justru lebih banyak mahasiswa yang memperolehnya.

Mahasiswa Program Studi Agribisnis Fakultas Pertanian Universitas Cokroaminoto Palopo Semester Genap Tahun Akademik 2017/2018 yang memprogramkan dan mengikuti mata kuliah pengetahuan komputer sebanyak 4 kelas (kelas 2A, 2B, 2C dan 2D) dengan jumlah mahasiswa 153 orang berdasarkan hasil penelitian memperlihatkan bahwa hampir semua mahasiswanya lulus dalam mata kulah ini. Hanya 12 mahasiswa atau sekitar 7,8\% yang tidak lulus dikarenakan mendapatkan nilai D (3 mahasiswa) dan E (9 mahasiswa).

Kelas $2 \mathrm{~A}$ lebih banyak mahasiswa yang mendapatkan nilai $\mathrm{A}$ dibanding mahasiswa di kelas lainnya. Di dalam 7 kategori penilaian, mahasiswa kelas $2 A$ mendapatkan ketujuh nilai tersebut. Kelas 2B lebih banyak mahasiswanya yang mendapatkan nilai B dibanding nilai dan kelas lain. Tidak ada mahasiswa yang mendapatkan nilai $C$ dan $D$ di kelas 2B. Kelas 2C tidak memperlihatkan unjuk kerja dominan dalam penilaian. Semua kategori nilai didapatkan dan pada nilai $\mathrm{A}$, mahasiswa kelas $2 \mathrm{C}$ memperlihatkan unjuk kerja yang negatif (paling sedikit mahasiswa yang memperolehnya). Kelas 2D merupakan kelas dengan mahasiswa yang terbanyak mendapatkan nilai $E$ dan tidak ada satupun mahasiswanya mendapatkan nilai $D$.

Hasil belajar di atas menunjukkan bahwa mahasiswa telah memperlihatkan performa yang baik selama perkuliahan. Hal ini sejalan dengan pendapat Dimyanti dan Mudjiono. Dimyanti dan Mudjiono (2006: 3) menyatakan bahwa hasil belajar merupakan hasil dari suatu interaksi tindak belajar dan tindak mengajar. Dari sisi guru, tindak mengajar diakhiri dengan proses evaluasi hasil belajar siswa. Dari sisi siswa, hasil belajar merupakan berakhirnya penggal dan puncak proses belajar.

Sudjana (2003: 3) menyatakan hasil belajar adalah perubahan tingkah laku yang timbul misalnya dari tidak tahu menjadi tahu. Sedangkan Slameto (1988: 23) menyatakan Hasil belajar adalah hasil pengukuran dan penilaian (evaluasi) pendidikan yang tidak hanya berguna 
untuk mengetahui penguasaan siswa atas berbagai hal yang pernah diajarkan atau dilatihkan, melainkan juga untuk memberikan gambaran tentang pencapaian program-program pendidikan secara lebih menyeluruh.

Dari dua pendapat di atas tentang hasil belajar, hasil belajar Mahasiswa Program Studi Agribisnis Fakultas Pertanian Universitas Cokroaminoto Palopo Semester Genap Tahun Akademik 2017/2018 yang memprogramkan dan mengikuti mata kuliah pengetahuan komputer sebanyak 4 kelas (kelas 2A, 2B, 2C dan 2D) dengan jumlah mahasiswa 153 orang berada pada kategori yang baik. Indikasinya adalah sebanyak 141 mahasiswa $(92,2 \%)$ yang lulus dalam mata kuliah ini.

\section{Kesimpulan}

Hasil penelitian telah mengungkapkan fakta yang ada tentang hasil belajar mata kuliah pengetahuan komputer Program Studi Agribisnis Fakultas Pertanian Universitas Cokroaminoto Palopo Semester Genap Tahun Akademik 2017/2018. Kesimpulan dari penelitian ini yang didasarkan pada hasil penelitian untuk menjawab permasalahan adalah:

1. Kelas $2 A$ lebih banyak mahasiswa yang mendapatkan nilai $A$ dibanding mahasiswa di kelas lainnya. Di dalam 7 kategori penilaian, mahasiswa kelas $2 \mathrm{~A}$ mendapatkan ketujuh nilai tersebut.

2. Kelas $2 B$ lebih banyak mahasiswanya yang mendapatkan nilai $B$ dibanding nilai dan kelas lain. Tidak ada mahasiswa yang mendapatkan nilai $\mathrm{C}$ dan $\mathrm{D}$ di kelas $2 \mathrm{~B}$.

3. Kelas $2 \mathrm{C}$ tidak memperlihatkan unjuk kerja dominan dalam penilaian. Semua kategori nilai didapatkan dan pada nilai $\mathrm{A}$, mahasiswa kelas $2 \mathrm{C}$ memperlihatkan unjuk kerja yang negatif (paling sedikit mahasiswa yang memperolehnya).

4. Kelas $2 \mathrm{D}$ merupakan kelas dengan mahasiswa yang terbanyak mendapatkan nilai $\mathrm{E}$ dan tidak ada satupun mahasiswanya mendapatkan nilai $\mathrm{D}$.

\section{Referensi}

Hamalik, O. (2008). Perencanaan Pengajaran Berdasarkan Pendekatan Sistem. Jakarta: PT Bumi Aksara

Sardiman, A.M. (2012). Interaksi dan Motivasi Belajar Mengajar. Jakarta: Rajawali.

Sudjana, N. (2003). Penilaian Hasil Belajar Mengajar. Bandung: PT. Remaja Rosdakarya. 